\title{
Establishment of ant communities in forests growing on former agricultural fields: Colonisation and 25 years of management are not enough (Hymenoptera: Formicidae)
}

\author{
Wouter DEKONINCK, Konjev DESENDER and PATRICK GROOTAERT \\ Royal Belgian Institute of Natural Sciences, Department Entomology, Vautierstraat 29, B-1000 Brussels, Belgium; \\ e-mail: wouter.dekoninck@natuurwetenschappen.be
}

Key words. Formicidae, diversity, community structure, afforestation, plantation, natural succession, former agricultural fields

\begin{abstract}
Ants are often considered as good indicators of change of management in different habitats. They have been used sporadically to evaluate large scale transformations involving reafforestation. In the present study, the ant assemblages at 15 forest sites are compared. The sites differ in history, age and forest management. Our results show that there are clear changes in ant assemblages with developmental stage but even after 25 years not all forest species are present. Natural succession and planting of trees with or without any other management, resulted in only open country species, and some from forest and wet grassland colonizing these new forests. Sometimes gynes of target forest species arrived in new forests from nearby mature forest, but apparently were unable to start a colony. We attribute this findings to the lack of appropriate vegetation structure and litter characteristics, which determines the forest ant fauna, more than the dispersal of ant gynes. Further investigations should enable us to predict if these conditions can be produced by $50-100$ or more years of forest succession and adequate management.
\end{abstract}

\section{INTRODUCTION}

Little is known about the responses of ants to forest planting or restoration. Colonization by ants of pastmining sites under different forest management regimes indicates that ant communities can recover and colonize these sites (Andersen, 1993; Bisevac \& Majer, 1999; Dunger et al., 2001; Holec \& Frouz, 2005; Ottonetti et al., 2006). However, there are few papers on how these social insects react to restoration measures such as natural succession (Dunger et al., 2001), reafforestation (Samways et al., 1996; Watt et al., 2002) and other forest management (Kotze \& Samways, 1999; 2001; Maeto \& Sato, 2004; Dauber \& Simmering, 2006). Despite the fact that in Western and Central European forests, ants represent an important part of the soil active arthropods (Czechowski et al., 1995) and play a major role in the biological decomposition of dead organic material (Seifert, 1986; 1996; Gotelli \& Ellison, 2002) and seed dispersal (Kjellsson, 1985; Gorb \& Gorb, 1999), long term studies on the effects of forest succession and afforestation or other types of forest management on ant communities in Europe are exceptional (Czechowski et al., 1995; SchlickSteiner et al., 2005). In Finland certain species present in 120 year old forests, had not (re)colonized areas of clear felled forests after 10 years because of the lack of food resources (Puntilla et al., 1991). Also Vepsäläinen et al. (2000) found that only a few ant communities of 35 year-old clear felled areas that had been ditched could be classified as forest communities. Even older (41-80 years) forest fragments in Finland still have a very different ant diversity compared to 140 year or older forest (Puntilla et al., 1994) and this is particularly so for wood ants and Serviformica species (Puntilla, 1996).
In Belgium ants can be very abundant and species-rich in dry heathlands and forests (Dekoninck et al., 2003) and xeromorphic calcareous grasslands (Dekoninck et al., 2007). Several species can act as indicators of longstanding undisturbed conditions. Colonization by these species of former agricultural fields is a slow process and a long time elapses before characteristic ant assemblages can become established in newly formed heathlands and oligotrophic grasslands (Dekoninck et al., 2001a, b). Probably this is also the case for ant communities typical of forests colonizing abandoned agricultural fields from nearby mature forests.

In the present study, the ant assemblages in different forest types of different origins are compared. This paper presents some of the results of a large project designed to evaluate the effects on former agricultural land of different forms of forest management (Dekoninck et al. 2005a). So far, papers on carabid and cicindelid beetles (Desender et al., 2005), spiders (De Bakker et al., 2005), terrestrial isopods (Dekoninck et al., 2005b) and centipedes (Lock et al., 2005) have been published. In general, target forest species of these terrestrial groups have colonized areas of new forest after 20-25 years. The species of carabids, terrestrial isopods and centipedes characteristic of mature forest are still lacking 20-25 years after reafforestation or natural succession. In some agricultural fields that were abandoned 20-25 years ago, eurytopic, generalist and common forest spider and carabid species are present but mostly in low numbers. Whether this also holds for ants is the main objective of this paper. We will therefore: (1) describe and characterize ant communities in 15 forest stands and compare ant diversities, habitat associations of each ant species and investigate whether 


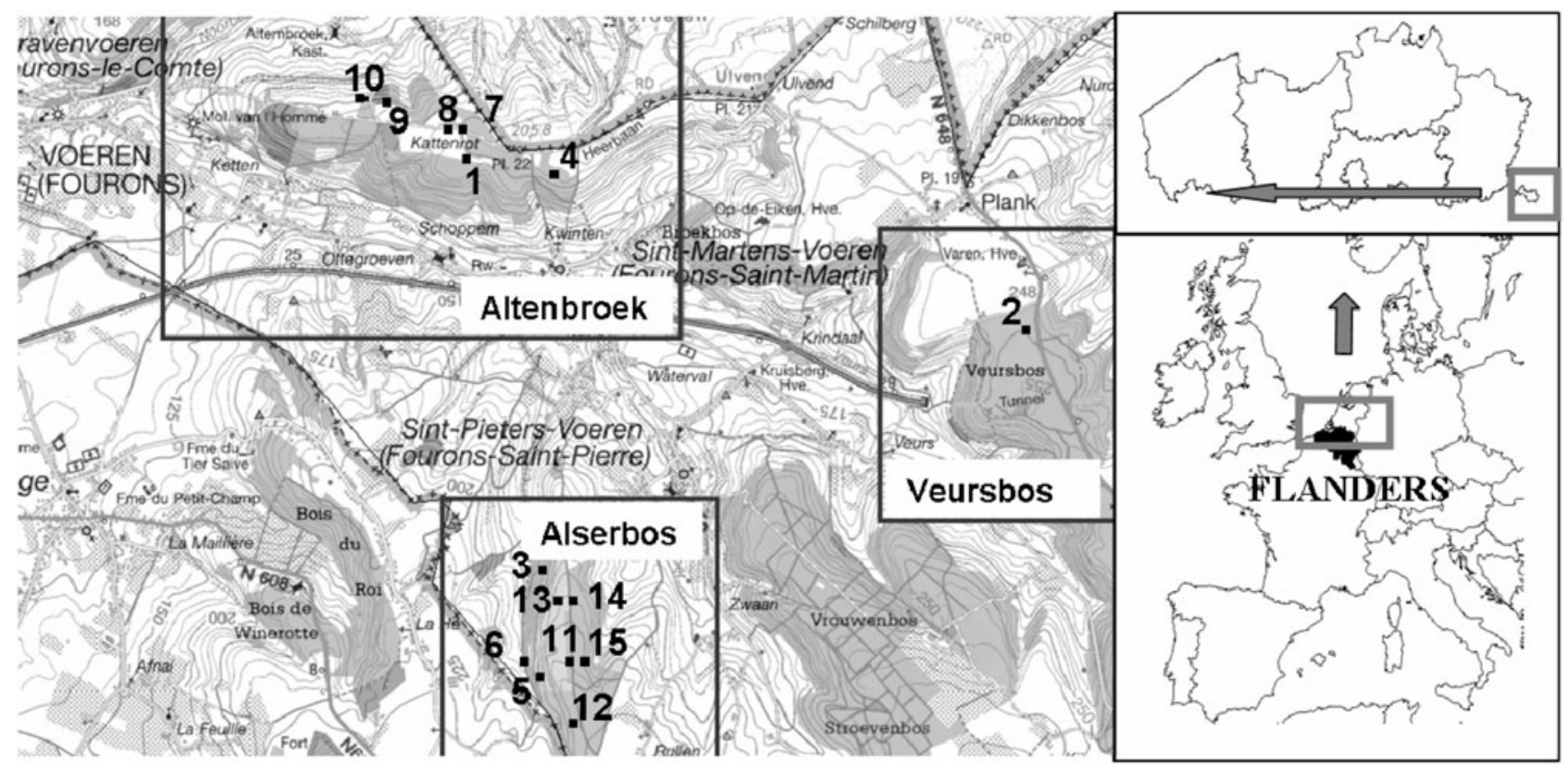

Fig. 1. Location of the 15 sites sampled in the three forest complexes of the Voeren region.

the distance to other habitats (i.e. open grassland) influences ant diversity; (2) identify the environmental conditions that determine ant communities in mature forests, newly planted forests and naturally established forests; (3) compare the effects of forest origin (natural succession versus reafforestation), former land use (grassland versus arable field) and successional stage [recent (7 years) versus older (20-25 years) and mature forest] on ant communities.

\section{MATERIAL AND METHODS}

\section{Study area}

In Western Europe, Flanders (northern part of Belgium), is one of the least forested regions. The majority of its forests are very small, highly fragmented and irregularly spaced (Tack et al., 1993; Dekeersmaeker et al., 2001). At present, forest cover in Flanders is less than $11 \%$ (150.000 ha) (Dumortier et al., 2005). At the beginning of the 1990s, the Flemish government decided to increase the forested area by 20,000 ha. In most cases, the only locations in Flanders that can be transformed into new forests are former grasslands and abandoned arable fields. The oldest reafforested sites in Flanders on loamy soils were former arable fields situated in the Voeren region (see Fig. 1).

In this region, typical deciduous mature forests are of beech (Fagus sylvatica L.), sessile oak [Quercus petraea (Mattuschka)] and hornbeam (Carpinus betulus L.) with an admixture of other deciduous trees such as sycamore (Acer pseudoplatanus L.) and birch Betula sp., and herbs like Luzula

TABLE 1. Historical background and general characteristics of all 15 forest sites sampled. MF - mature forest; NS - forests resulting from natural succession; PL - reafforestation - plantations; $\mathrm{Ar}$ - forest succession on former arable fields; $\mathrm{Gr}$ - forest succession on former grassland, val - forest in valleys, < 1775: forest present before de Ferraris maps; * extensive grazing by Galloway cattle.

\begin{tabular}{cccclcc}
\hline Site & Forest & Code & History & Description of the site & Forested since Distance to grassland (in m) \\
\hline Site01 & Altenbroek & MF1 & MF & Mature oak-birch forest & $<1775$ & 37.5 \\
Site02 & Veursbos & MF2 & MF & Mature oak-beech forest & $<1775$ & 238 \\
Site03 & Alserbos & MF3 & MF & Mature oak-birch forest & $<1775$ & 100 \\
Site04 & Altenbroek & MF4 & MF val & Mature mixed deciduous forest & $<175$ & 48 \\
Site05 & Alserbos & MF5 & MF val & Mature mixed deciduous valley forest & $<1775$ & 26 \\
Site06 & Alserbos & MF6 & MF val & Mature mixed deciduous valley forest & 1996 & 15 \\
Site07 & Altenbroek & yNS1 & Ar* & Natural succession, Salix sp. and birch & 1996 & 7.5 \\
Site08 & Altenbroek & yNS2 & Gr* & Natural succession, no shrubs or trees & 1996 & 7 \\
Site09 & Altenbroek & yNS3 & Ar* & Natural succession, Salix sp. and birch & 1989 & 43 \\
Site10 & Altenbroek & PL1 & Ar & Reafforestaton by Planting of Quercus robur & $1985-1990$ & 203 \\
Site11 & Alserbos & PL2 & Gr & Reafforestation by Planting of Prunus avium & 197 \\
Site12 & Alserbos & PL3 & Gr & Reafforestation by Planting of Quercus robur & $1985-1990$ & 1980 \\
Site13 & Alserbos & oNS1 & Gr & Natural succession of birch & 1980 & 217 \\
Site14 & Alserbos & oNS2 & Ar & Natural succession of birch & 1980 & 178 \\
Site15 & Alserbos & oNS3 & Ar & Natural succession of birch & & 135 \\
\hline
\end{tabular}


TABLE 2. Variables for each site and averages for the different forest types. Coverages of bare ground, grasses, shrubs $(<3 \mathrm{~m})$, herbs, trees $(>3 \mathrm{~m})$, mosses and leaf-litter are presented in \%. Humus depth was measured in $\mathrm{cm}$. Vegetation height is the average of 30 randomly taken measurements of vegetation height, and vegetation heterogeneity was the estimated standard deviation.

\begin{tabular}{crrrrrrrrrrrr}
\hline \multirow{2}{*}{$\begin{array}{c}\text { Site } \\
\text { forest type }\end{array}$} & \multicolumn{1}{c}{$\begin{array}{c}\text { Bare } \\
\text { ground }\end{array}$} & Grass & Shrubs & Herbs & Trees & Mosses & Litter & & Humus & $\begin{array}{c}\text { Vegetation } \\
\text { height }\end{array}$ & $\begin{array}{c}\text { Vegetation } \\
\text { heterogeneity }\end{array}$ \\
\hline MF1 & 6.67 & 0.33 & 26.67 & 5.00 & 76.67 & 1.67 & 91.67 & 3.00 & 0.67 & 2.38 \\
MF2 & 3.00 & 0.00 & 40.00 & 8.00 & 45.00 & 0.00 & 88.33 & & 3.50 & 110.00 & 45.00 \\
MF3 & 5.00 & 0.00 & 13.33 & 80.00 & 50.00 & 0.00 & 80.00 & & 1.00 & 1.69 & 0.83 \\
MF4 & 20.00 & 0.00 & 9.00 & 50.00 & 56.67 & 0.00 & 60.00 & & 1.50 & 11.83 & 12.12 \\
MF5 & 10.00 & 15.00 & 26.00 & 48.33 & 66.67 & 3.67 & 36.67 & & 1.50 & 15.00 & 22.00 \\
MF6 & 10.00 & 14.00 & 11.67 & 65.00 & 83.33 & 3.67 & 36.67 & & 1.50 & 18.00 & 20.00 \\
\hline Average MF & 9.11 & 4.89 & 21.11 & 42.72 & 63.06 & 1.50 & 65.56 & & 2.00 & 26.20 & 17.06 \\
\hline yNS1 & 0.00 & 53.33 & 56.67 & 36.67 & 0.00 & 8.33 & 0.00 & & 2.00 & 77.83 & 45.58 \\
yNS2 & 0.00 & 83.33 & 0.00 & 13.33 & 0.00 & 5.00 & 0.00 & & 2.00 & 25.27 & 22.21 \\
yNS3 & 13.33 & 50.00 & 46.67 & 7.00 & 0.00 & 10.00 & 16.67 & & 1.00 & 102.47 & 66.60 \\
\hline Average yNS & 4.44 & 62.22 & 34.44 & 19.00 & 0.00 & 7.78 & 5.56 & & 1.67 & 68.52 & 44.80 \\
\hline PL1 & 5.00 & 0.00 & 5.33 & 1.33 & 78.33 & 3.00 & 85.00 & & 2.00 & 10.70 & 21.67 \\
PL2 & 0.00 & 80.00 & 50.00 & 15.00 & 0.00 & 10.00 & 0.00 & & 2.00 & 12.00 & 5.00 \\
PL3 & 5.00 & 2.00 & 1.00 & 10.00 & 80.00 & 2.67 & 90.00 & & 3.00 & 28.07 & 43.57 \\
\hline Average PL & 3.33 & 27.33 & 18.78 & 8.78 & 52.78 & 5.22 & 58.33 & & 2.33 & 16.92 & 23.41 \\
\hline oNS1 & 5.00 & 0.00 & 20.00 & 71.67 & 80.00 & 65.00 & 40.00 & & 2.00 & 105.00 & 59.00 \\
oNS2 & 5.00 & 40.00 & 40.00 & 55.00 & 60.00 & 78.33 & 20.00 & & 2.00 & 80.00 & 35.00 \\
oNS3 & 4.00 & 24.33 & 4.33 & 23.00 & 41.67 & 43.33 & 26.67 & & 3.00 & 17.47 & 15.01 \\
\hline Average oNS & 4.67 & 21.44 & 21.44 & 49.89 & 60.56 & 62.22 & 28.89 & 2.33 & 67.49 & 36.34 \\
\hline & & & & & & & & & & \\
\hline
\end{tabular}

luzuloides (Lam.) Dandy \& Wilmot, Hedera helix Linnaeus and Lily-of-the-valley (Convallaria majalis Linnaeus).

\section{Sample sites}

In total, 15 sites were selected in three nearby forests in the Voeren region (map: Fig. 1; further details: Table 1). All 15 sites can be placed in one of 7 types of stand: MF - Mature forest $(n=6) ; \mathrm{NS}$ - natural succession $(\mathrm{n}=6) ; \mathrm{PL}$ - reafforestation with saplings ( $1-2$ meter high) $(\mathrm{n}=3)$; Ar - natural succession on former arable fields $(\mathrm{n}=5)$; $\mathrm{Gr}$ - natural succession on former grassland $(\mathrm{n}=4) ; \mathrm{y}-$ young forests resulting from natural succession, 7 years old $(\mathrm{n}=3)$ and $\mathrm{o}$ - older forests after 20-25 years of natural succession $(n=6)$.

\section{Sampling techniques and identification}

At each site, three pitfall traps (diameter of $9.5 \mathrm{~cm}$ ) filled with $3.5 \%$ formaldehyde solution plus detergent were placed $3-5 \mathrm{~m}$ apart in a row. One Malaise trap was used to collect flying queens and males (Dunn et al., 2007), fitted with a vial filled with $75 \%$ alcohol solution in each of the young forests and two mature forests.

All traps were emptied fortnightly from April until October 2003 (12 periods). All ants were identified using Seifert (1996). Workers, males, alate (queen with wings) and dealate gynes (wingless queen) were counted separately.

\section{Characterization of the environmental variables of the dif- ferent sampling sites}

Around each trap $(n=45)$ the percentage of ground covered of each abundant plant species was estimated in a $2 \times 2 \mathrm{~m}$ area and from that the ground cover (in \%) of grasses, herbs, shrubs $(<3 \mathrm{~m})$, trees $(>3 \mathrm{~m})$, leaf-litter, mosses and bare ground was assessed. Averages of these variables for each site and forest type are given in Table 2. At each site vegetation height was the average height of 30 randomly taken measurements of the height of the herbaceous plants and vegetation heterogeneity (= vegetation structure) was the estimated standard deviation of these 30 measurements. Humus depth was measured in $\mathrm{cm}$.

\section{Habitat preferences of ants in Flanders}

Habitat preferences were defined based on those recorded for Flanders (Dekoninck et al., 2003), Belgium (van Boven \& Mabelis, 1986) and central Europe (Seifert, 1996). Three categories of habitat preference were relevant to the species of ants recorded in this study: forests (FOR), forest and wet grasslands (FOR WG) and open habitats (OPEN) (see Table 3). Differences in the numbers of species in mature forests $(n=6)$, young forests resulting from natural succession $(n=3)$, old forests resulting from natural succession $(n=3)$ and plantations $(n=3)$ were tested using unbalanced analysis of variance (ANOVA).

\section{Data analyses}

Data were analysed using non-parametric correlations (numbers of species versus distance from open grassland). To detect variation in species composition among the sites and the relation of species composition to environmental variables, a detrended correspondence analysis (DCA) was used. It is an indirect multivariate technique that positions samples along orthogonal axes that sequentially explain the greatest amount of inter-sample variation and was done using the program PC Ord 4.0 package (Mc Cune \& Grace, 2002). Each site was treated as an independent unit in the analysis and data (capture rates) from the 3 pitfall traps at each site were pooled. The capture rates (number of workers per site) were modified using the "Relativization by Maximum" option in the program PC Ord 4.0 and for the DCA rare species were downweighted. 
TABle 3. Abundance of ants at 15 sites in 3 forests in the Voeren region with their habitat preference. When sexuals were found the numbers are given between parenthesis: first dealate, then alate gynes and males. Under habitat FOR - target forest species, FOR WG - species from forest and wet grasslands and OPEN - species from open habitats.

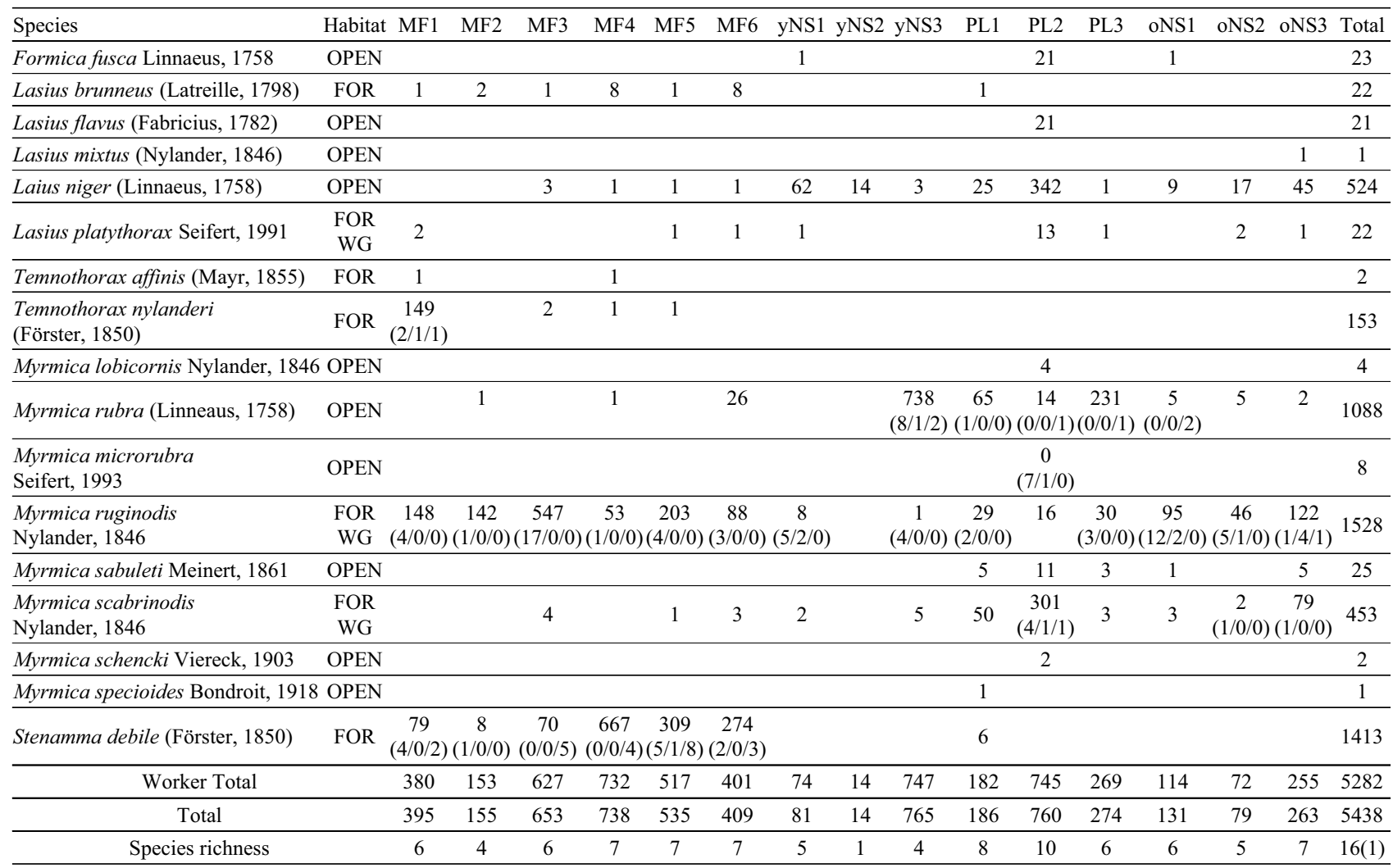

\section{RESULTS}

\section{General results}

During the sampling a total of 5438 ants were collected by the pitfall traps, including 5282 workers, 31 males, 100 dealate gynes and 14 alate gynes. We collected 16 species, which is $35 \%$ of all known Belgian ant species (Dekoninck et al., 2006). The name of each species (name of author's description and year), the relative abundance of workers and numbers of alate, dealate gynes and males at the different sites are given in Table 3. Eight microgynes of Myrmica rubra (miniature queens, sometimes also reproductive variant of the normal reproductive queens, the macrogyne) were collected in the Prunus avium Linneaus plantation growing on former grassland in the Alserbos, but as its species status is questioned by Steiner et al., 2006, it was not considered to be a valid species (i.e. Myrmica microrubra) in the analyses. However it is separated from M. rubra in Table 3.

The most abundant species was Myrmica ruginodis making up $28 \%$ of all the specimens. Except at sites yNS2 and PL2 (both former grasslands) this species was one of the top three ranked ant species.

\section{Habitat preference and diversity}

Species from forests (FOR) were only found in mature forests. In young forests resulting from natural succession and 20-25 year old forests, they were absent (Fig. 2) except at one plantation at Altenbroek in a former arable field. The numbers of OPEN species and other non forest species were low in the mature forests. The contribution of OPEN species was significantly higher in the plantation than in the young and old forests resulting from natural succession and mature forests (ANOVA: $\mathrm{df}=3, \mathrm{~F}$ $=7.11, \mathrm{p}<0.01)$. In the young and 20-25 year old forest, the numbers of non forest species increased with increasing total species richness. FOR WG species were equally represented in all groups of forests (ANOVA: df $=3, \mathrm{~F}=0.800, \mathrm{p}=0.481$ ).

Species richness was not correlated with any of the vegetation variables (all Spearman rank correlation $\mathrm{r}<$ 0.05 ) or particular type of forest (ANOVA: $\mathrm{df}=3, \mathrm{~F}=$ $4.81, \mathrm{p}>0.01)$. The species richness of the Alserbos sites $(\mathrm{n}=8$, mean $=6.750, \mathrm{SD}=1.488)$ was higher than those at Altenbroek $(\mathrm{n}=6$, mean $=5.167, \mathrm{SD}=2.483)(\mathrm{t}$-test: $\mathrm{t}$ $=-1.1492$ and $p=0.162)$. Highest species richness in both forest complexes was in a 20-25 year old plantation (resp. PL1 and PL2). Distance to open grassland did not seem to influence species richness (Spearman rank correlation $r=0.0495$ ).

\section{Multivariate assemblage analysis and correlations with environmental variables}

As revealed by the DCA analysis (Fig. 3A, B) ant assemblages were structured according to forest developmental stage but not forest complexity. Mature forests clustered together unlike those on former agricultural fields (Fig. 3A and B). In forests resulting from natural succession and plantations, FOR species were absent but OPEN and FOR WG species were present. The coverages 


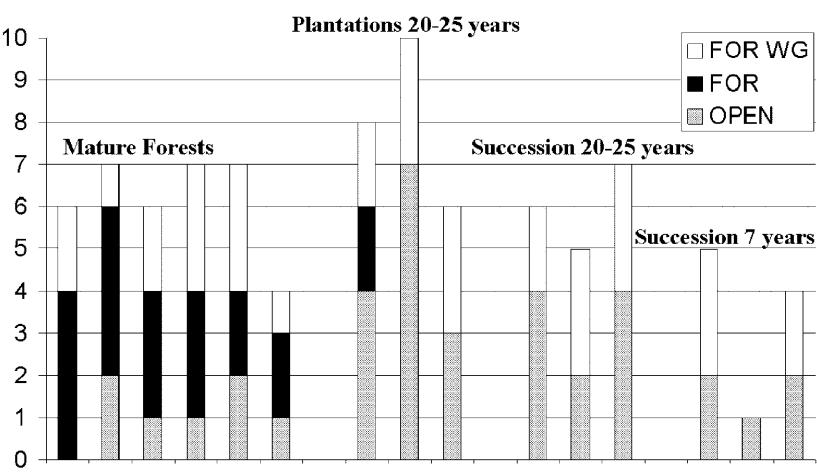

Fig. 2. Number of species of ants from forests, open sites and non-forest sites and forests and wet grasslands collected at each site (FOR - target forest species, FOR WG - species from forest and wet grasslands and OPEN - species from open habitats).

of litter and bare ground were positively correlated with the first axis (Table 4). The coverage of grass was significantly negatively correlated with this axis. Some of the FOR species were significantly positively correlated with the first axis.

\section{Additional catches of gynes by Malaise traps}

All gynes caught by the Malaise traps are presented in Table 5. At one 20 year old forest resulting from natural succession, a dealate gyne of Lasius brunneus was found. At one young forest resulting from natural succession, a former arable field, one dealate gyne of Temnothorax nylanderi was collected. Workers of both forest species were lacking at these sites (no individuals were observed or caught in pitfall traps).

\section{DISCUSSION}

\section{Ant diversity, community structure and environmental variables}

In forests consisting of a mosaic of sites of different ages or subject to different forest management, ant assemblages can be highly structured and mainly associated with developmental stage (Puntilla et al., 1994; Czechowski et al., 1995; Vepsäläinen et al., 2000). This was also the case in the forests we studied. The most important vegetation characteristics determining mature ant assemblages are the coverage of trees and shrubs and development of a leaf-litter layer. In young forests, the extent of the grass cover is important in determining the assembly composition. During forest succession ants are known to depend principally on epigaeic habitats and vegetation heterogeneity with the vegetation and landscape structure determining the occurrence and abundance of ants (Czechowski et al., 1995; Dunger et al., 2001; Maeto \& Sato, 2004; Markó et al., 2004; Lafleur et al., 2006; Ottonetti et al., 2006). During the succession from agricultural land to forest, vegetation structure and the composition of the vegetation layers change continu-
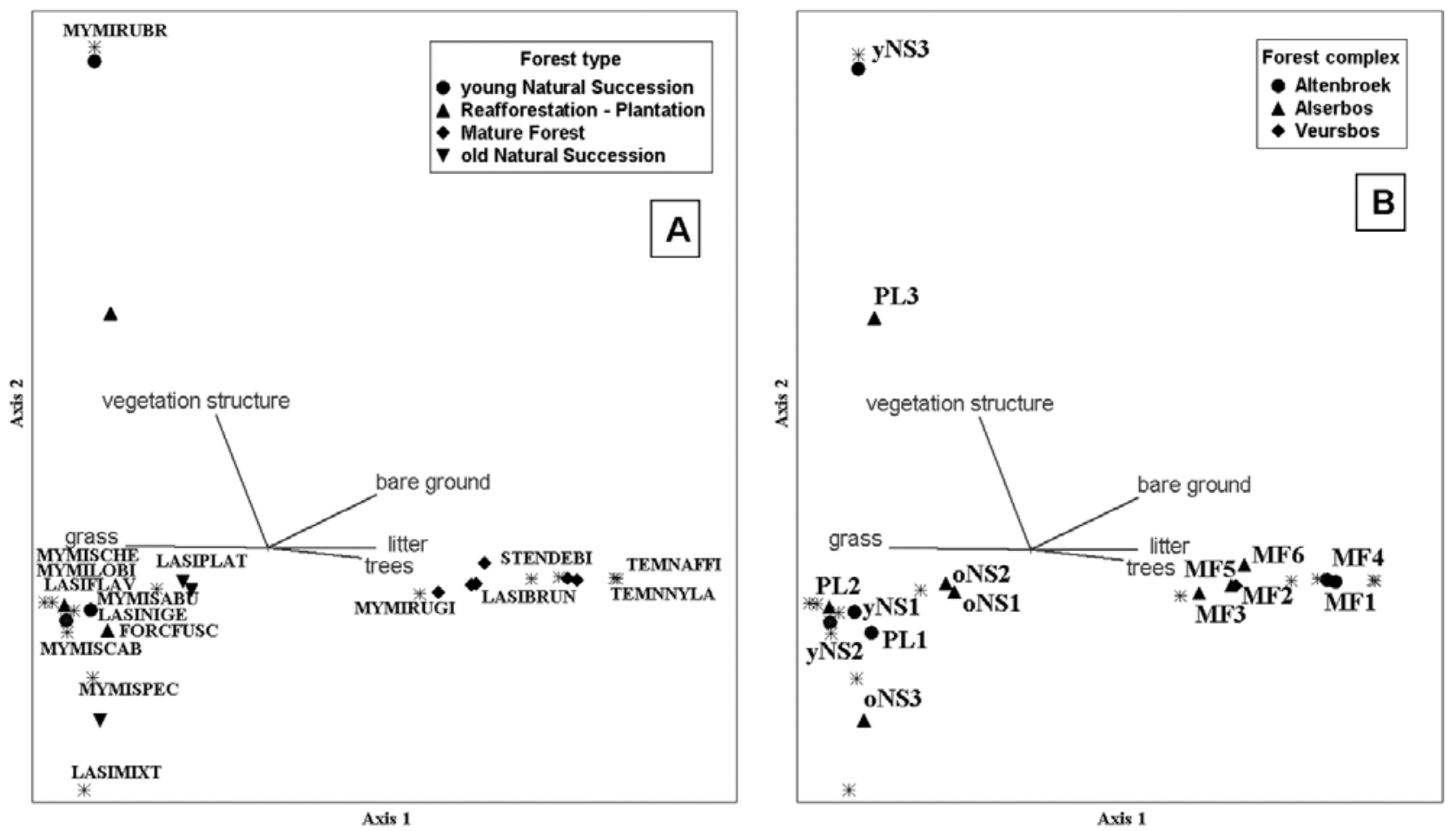

Fig 3. DCA-biplot diagram (As1 en As2) of all sites based on the relative abundances of the different species collected during the project, with the sites marked by a $\boldsymbol{\Delta}$ along with their history (codes see Table 1) and the species presented by * (MYMIRUBR Myrmica rubra, MYMIRUGI - Myrmica ruginodis, MYMISCAB - Myrmica scabrinodis, MYMISABU - Myrmica sabuleti, MYMISPEC - Myrmica specioides, MYMILOBI - Myrmica lobicornis, MYMISCHE - Myrmica schencki, FORCFUSC - Formica fusca, LASIBRUN - Lasius brunneus, LASIFLAV - Lasius flavus, LASINIGE - Lasius niger, LASIMIXT - Lasius mixtus, LASIPLAT - Lasius platythorax, TEMNAFFI - Temnothorax affinis, TEMNNYLA - Temnothorax nylanderi, STENDEBI - Stenamma debile). The Eigenvalues of the first three axis are: Axis1 $=0.89$, Axis $2=0.73$ and Axis $3=0.36$. 
TABLE 4. Inter-site correlations for 10 variables for the DCA analysis, with all significant correlations in bold (Pearson Product Moment Correlation $\mathrm{n}=15, \mathrm{p}<0.05$ if $\mathrm{r}>0.514$ ). Variables are the ground covered by bare ground, grasses, shrubs $(<3 \mathrm{~m})$, herbs, trees $(>3 \mathrm{~m})$, mosses and leaf-litter. Humus depth was measured in $\mathrm{cm}$. Vegetation height is an average of 30 randomly taken measurements of vegetation height and vegetation heterogeneity was the estimated standard deviation.

\begin{tabular}{lccc}
\hline \multirow{2}{*}{ Variable } & Axis1 & Axis2 & Axis3 \\
\cline { 2 - 4 } & $\mathrm{r}$ & $\mathrm{r}$ & $\mathrm{r}$ \\
\hline Bare ground & $\mathbf{0 . 5 4 1}$ & 0.376 & -0.450 \\
Grass & $\mathbf{- 0 . 6 2 0}$ & 0.066 & 0.116 \\
Shrubs & -0.105 & 0.207 & 0.177 \\
Herbs & 0.343 & -0.262 & -0.358 \\
Trees & 0.501 & -0.168 & -0.084 \\
Mosses & -0.334 & -0.168 & 0.219 \\
Litter & $\mathbf{0 . 5 3 7}$ & 0.022 & 0.101 \\
Humus & 0.046 & -0.239 & 0.329 \\
Vegetation height & -0.262 & 0.352 & 0.157 \\
Vegetation heterogeneity & -0.373 & 0.599 & 0.036 \\
\hline
\end{tabular}

ously and thus the habitat suitability for ants also changes during this process (Dauber \& Simmering, 2006). When forest populations are small and time is short, plantations may be the faster way of obtaining and maintaining typical ant assemblages in forests.

\section{Target species for different developmental stages}

In this study, the target forest species were almost exclusively confined to mature forests. The presence of a closed canopy in mature forest may account for this (Oinonen, 1956; Puntilla et al., 1991, 1994; Maeto \& Sato, 2004; Ottonetti et al., 2006).

In very young forests the influence of former agricultural activities is still apparent and can probably explain the lack of an ant assemblage (Siepel et al., 1989). Lasius niger was the only ant species that colonized and became established in the young forests resulting from natural succession on former grassland. This species is eurytopic and typical of recently disturbed sites (Czechowski et al., 1995; Boer, 1998; Dekoninck et al., 2003, Dauber \& Simmering, 2006). When the species is replaced by FOR WG species such as Myrmica ruginodis, M. scabrinodis and Lasius platythorax, afforestation and forest succession are developing positively (Czechowski et al., 1995). In eastern Germany a study on the development of soil fauna following reafforestation of former mining sites, showed that after 24 years, and even more so after 35-36 years, open canopy preferring pioneer ant species (as Lasius niger and Tetramorium caespitum), were replaced by species such as Stenamma debile, L. platythorax, M. rubra and M. ruginodis (Dunger et al., 2001). We suggest that the latter 3 species can be used to check and evaluate reafforestation and forest succession after a period of 20-25 years.

\section{5 years of forest management is not enough}

Several authors record that in the initial stages of forest succession ant communities can differ considerably, while later they become similar (Czechowski et al., 1995; Ottonetti et al., 2006). Here the impact of former land use history (grassland or crop field) and type of forest succession (planting vs natural succession) become less important in determining differences between ant assemblages 25 years after reafforestation or start of natural succession. However, a typical forest assemblage was not present after 25 years. Also elsewhere significant differences in ant communities are still present after 46 years (Dunger et al., 2001) and 47-79 years in forests resulting from natural succession (Lafleur et al., 2006) and 40-70 years after plantation (Maeto \& sato, 2004). An important limiting factor determing the establishment of forest species in a new forest after 50-100 or even 150 years of forest succession may be the lack or shortage of dead and dying wood, and insufficient food (Puntilla et al., 1994). There are no new forests with an age of more than 25 years old in our data set, and no dead wood trunks or dying stumps on these former agricultural fields. It is difficult to judge how long it would take before FOR species become established in these new forests. In order to deter-

TABLE 5. Gynes collected with Malaise traps (AGY - alate gyne; DGY - deleate gyne).

\begin{tabular}{|c|c|c|c|c|c|c|c|c|c|c|}
\hline \multirow[t]{2}{*}{ Species } & \multicolumn{2}{|c|}{ Mature forest } & \multicolumn{3}{|c|}{$\begin{array}{c}\text { Young new forest in the } \\
\text { Altenbroek }\end{array}$} & \multicolumn{5}{|c|}{$\begin{array}{l}\text { New forest in the Alserbos } \\
20-25 \text { years }\end{array}$} \\
\hline & MF1 & MF3 & yNS1 & $\mathrm{yNS3}$ & PL1 & oNS1 & oNS2 & PL2 & oNE3 & PL3 \\
\hline Temnothorax nylanderi & $6 \mathrm{AGY}$ & & $1 \mathrm{AGY}$ & & & & & & & \\
\hline Stenamma debile & & $1 \mathrm{AGY}$ & & & & & & & & \\
\hline Lasius brunneus & & $1 \mathrm{AGY}$ & & & & & $1 \mathrm{AGY}$ & & & \\
\hline Myrmica ruginodis & $1 \mathrm{AGY}$ & $2 \mathrm{AGY}$ & & $1 \mathrm{AGY}$ & $1 \mathrm{AGY}$ & $\begin{array}{l}3 \mathrm{AGY} \\
\text { / } 3 \mathrm{DGY}\end{array}$ & $\begin{array}{l}1 \mathrm{AGY} \\
3 \mathrm{DGY}\end{array}$ & $1 \mathrm{AGY}$ & & \\
\hline \multicolumn{11}{|l|}{ Microgyne of } \\
\hline Myrmica ruginodis & & & & $4 \mathrm{AGY}$ & & & & $1 \mathrm{AGY}$ & & \\
\hline Lasius bicornis & & & & & & & & & & $1 \mathrm{AGY}$ \\
\hline Myrmica rugulosa & & & & & & & & & $1 \mathrm{AGY}$ & \\
\hline Myrmica scabrinodis & & $1 \mathrm{AGY}$ & & & & & & $1 \mathrm{AGY}$ & & \\
\hline Myrmica sabuleti & & & & & & & & & $1 \mathrm{AGY}$ & \\
\hline
\end{tabular}


mine this the ant faunas of several 50-100-150-200 year old forests need to be studied in the same region.

\section{Colonisation and establishment of target forest species}

The presence of workers in pitfall traps at different times may indicate the presence of site specific species. The presence of ant gynes in pitfall traps has to be interpreted with caution because this is not necessarily related to the presence of a nearby colony (Schlick-Steiner et al., 2005): pitfall caught alate gynes may have come from a nearby nest or from a great distance. A dealate gyne may just be one that has finished its nuptial flight or, in some species, a foraging queen from a nearby older colony.

The occassional records from Malaise traps indicate that sometimes gynes of target forest species are able to reach a new forest from nearby mature forest, but unable to start a colony because workers have not been observed at this site. Probably they need more typical vegetation and litter characteristics for survival. This also explains the long period that elapses before forest ant assemblages can colonise and persist, and indicates that the main factor in this process is not lack of colonisation by alate gynes but unfavourable local conditions.

\section{Implications and possibilities of pitfall sampling of ant communities for diversity studies}

Although the use of pitfall trapping to collect ants in Western and Central Europe is criticised (e.g. Seifert, 1990, Laeger \& Schultz, 2005; Schlick-Steiner et al., 2006), many studies use capture rates to estimate the relative abundance of particular species at simultaneously sampled sites and assess the habitat preference of these species (Retana \& Cerdá, 2000; Schlick-Steiner et al., 2005; Steiner et al., 2005; Botes et al., 2006; Dauber \& Simmerling, 2006; Ottonetti et al., 2006). Especially when collected over a long period at not too structurally complex sites, such catches give a good estimate of the relative abundance of each species at a site, as shown for calcareous grasslands in Belgium by Dekoninck et al., 2007. In contrast, in short studies of only a few days (48h: Steiner \& Schlick-Steiner 2004; Steiner et al., 2005; Schlick-Steiner et al., 2006; one week: Dauber \& Simmering, 2006) some of the species present may not be caught. Our experience of sampling at similar sites over a period of more than 6 months indicates that even species that are difficult to catch with pitfall traps (because they are mostly subterranean, like Lasius flavus and Lasius mixtus, or have small colonies like Myrmica lobicornis) were caught at least once (Dekoninck et al., in press).

We did not observe a higher species richness at sites close to edges or other habitats. Species richness of ants in small plots sampled by pitfall traps has to be interpreted with caution. Frequently, high ant species richness is used as a measure of the high nature value of a particular site (Dekoninck et al., 2003, 2007; Dauber \& Simmering, 2006) or suggests how successful (Diehl et al., 2004) or fast (Bisevac \& Majer, 1999) the rehabilitation process has been. This is not always the case. Sometimes very small sites and edges can have high ant species richness with high relative abundances because of catches of species from nearby habitats (Steiner \& Schlick-Steiner, 2004). Sometimes small patches also have more heterogeneous resources and habitats, allowing more species to temporal exploit of these small patches.

\section{CONCLUSIONS}

Our results show that is takes a long time for ant species typical of forests to establish themselves in new forest stands on former agricultural fields. Even after 20-25 years of natural succession or reafforestation, with or without management, typical ant forest assemblages for this region were still absent. This corroborates the results obtained for other soil active invertebrates studied during this project (spiders: De Bakker et al., 2005; terrestrial isopods: Dekoninck et al., 2005b; carabid and cicindelid beetles: Desender et al., 2005; centipedes: Lock et al., 2005). In general, colonization by soil active invertebrates of former agricultural fields takes a long time. This is especially true for colonial invertebrates such as ants because the establishment of nests takes time. Not only the development of typical ant assemblages in forests, but also in other restored habitats such as mature grassland or heath takes more than 20-25 years (Bisevac \& Majer, 1999; Dekoninck et al., 2001a, b; Boer, 2004). Although typical vegetation can be present a few years after the transformation of former agricultural fields, the complete development of animal assemblages takes a considerably longer time, which highlights the necessity to consider invertebrates in restoration schemes.

ACKNOWLEDGEMENTS. We would like tot thank AMINAL afdeling Bos \& Groen for financial support (project: AMINAL/B\&G/30/2002) and A. Zeevaart conservator of the Alserbos in Sint-Pieters-Voeren for authorisation to sample there. We also would like to thank M. Konvička and three anonymous referees for critically reading this manuscript and $\mathrm{F}$. Hendrickx for helpful comments on an earlier version of the manuscript.

\section{REFERENCES}

ANDERSEN A.N. 1993: Ants as indicators of restoration success at a uranium mine in Tropical Australia. Restor. Ecol. 1(3): 156-167.

BISEVAC L. \& MAJER J.D. 1999: Comparative study of ant communities of rehabilitated mineral sand mines and heathland, Western Australia. Restor. Ecol. 7(2): 117-126.

BOER P. 1998: Mieren als natuurontwikkelaars. [Ants as nature developers.] Nieuwe Wildernis 3: 4-7.

Boer P. 2004: Gemier in Plan Goudplevier. [Ants in Plan Goudplevier.] Levende Nat. 105: 72-75.

Botes A., McGeoch M.A., Robertson H.G. van Niekerk A., DAvids H.P. \& ChOwn L.S. 2006: Ants, altitude and change in the northern Cape Floristic Region. J. Biogeogr. 33: 71-90.

van Boven J.K.A. \& Mabelis A.A. 1986: De mieren van de Benelux. [The ants of the Benelux.] Wet. Med. KNNV 173: $1-64$.

Czechowski W., Pisarski B. \& Yamauchi K. 1995: Succesion of ant communities (Hymenoptera, Formicidae) in moist pine forests. Fragm. Faun. 24: 447-488.

Dauber J. \& Simmering D. 2006: Ant assemblages in successional stages of Scotch Broom stands (Hymenoptera: Formicidae; Spermatophyta). Myrmecol. Nachr. 9: 53-64. 
De Bakker D., Baert L., Dekoninck W. \& De Koninck H. 2005: The impact of spontaneous and induced afforestation on spider diversity in the Voeren-region. Bull. Konin. Belg. Inst. Natuurwet. (Entomol.) 75: 235-251.

Dekeersmaeker L., Rogiers N., Lauriks R. \& De Vos B. 2001: Ecosysteemvisie Bos Vlaanderen, Ruimtelijke uitwerking van de natuurlijke bostypes op basis van bodemgroeperingseenheden en historische boskaarten. Eindverslag van project Vlina C97/06, studie uitgevoerd voor rekening van de Vlaamse Gemeenschap binnen het kader van het Vlaams Impulsprogramma Natuurontwikkeling in opdracht van de Vlaamse minister bevoegd voor natuurbehoud. $75 \mathrm{pp}$.

Dekoninck W., Versteirt V. \& Grootaert P. 2001a: Praktijkgericht onderzoek naar kansen en belangrijke stuurvariabelen voor natuurontwikkeling op gronden met voormalig intensief landbouwgebruik. Partim Invertebraten VLINA99/02. Rapport ENT.2001.05. KBIN, Brussel, 262 pp.

Dekoninck W., Versteirt V. \& Grootaert P. 2001b: Rediscovery of a colony Polyergus rufescens (Latreille, 1798) in Belgium: Observations at the "Hageven" Nature reserve (Hymenoptera, Formicidae). Bull. Soc. R. Belge Entomol. 137: $98-101$.

Dekoninck W., Vankerkhoven F. \& Maelfait J.-P. 2003: Verspreidingsatlas en voorlopige Rode Lijst van de mieren van Vlaanderen. [Distribution Maps and a Provisional Red List of the Ants of Flanders.] Rapport van het Instituut voor Natuurbehoud 2003.07. Brussel, $191 \mathrm{pp.}$

Dekoninck W., Desender K., Grootaert P. \& Maelfait J.-P. 2005a: Afforestation, plantation and extensive grazing on formerly agricultural sites and the influences on different arthropod-groups: a case-study in the Voeren-region. Bull. Konin. Belg. Inst. Natuurwet. (Entomol.) 75: 221-234.

Dekoninck W., Maelfait J.-P., Desender K. \& Grootaert P. 2005b: Comparative study of the terrestrial isopod faunas from ancient forests and afforested former agricultural fields. Bull. Konin. Belg. Inst. Natuurwet. (Entomol.) 75: 271-279.

Dekoninck W., Maelfait J.-P., Vankerckhoven F., Baugnée J.-Y. \& Grootaert P. 2006: An update of the checklist of the Belgian ant fauna with comments on new species for the country (Hymenoptera, Formicidae). Belg. J. Entomol. 8: $27-41$.

Dekoninck W., De Koninck H., Baugnée J.-Y. \& Maelfait J.-P. 2007: Ant biodiversity conservation in Belgian calcareous grasslands: active management is vital (Hymenoptera : Formicidae). Belg. J. Zool. 137: 137-146.

Dekoninck W., Hendrickx F., Dethier M. \& Maelfait J.-P. (in press): Spontaneous afforestation endangers the special ant fauna of abandoned quarries along the river Meuse (Wallonia, Belgium). Restor. Ecol.

Desender K., Dekoninck W. \& Grootaert P. 2005: Diversity and assemblages of Carabid beetles in ancient forests and afforested former agricultural land. Bull. Konin. Belg. Inst. Natuurwet. (Entomol.) 75: 253-265.

Diehl E., Sanhudo C.E.D. \& Diehl-Fleig E. 2004: Grounddwelling ant fauna of sites with high levels of copper. Braz. J. Biol. 64: 33-39.

Dumortier M., De Bruyn L., Wils C., Paelinckx D., Vander Mijnsbrugge K., Cox K., Sioen G., Roskamp P., VandenkerkHove K. \& Hens M. 2005: Bossen en struwelen. [Forests and scrub.] In Dumortier M., De Bruyn L., Hens M., Peymen J., Schneiders A., Van Daele T., Van Reeth W., Weyembergh G. \& Kuijken E. (eds): Natuurrapport 2005. Toestand van de natuur in Vlaanderen: Cijfers voor het beleid. Mededeling van het Instituut voor Natuurbehoud No. 24. Brussel, pp. $115-128$.
Dunger W., Wanner M., Hauser H., Hohberg K., Schulz H.-J., Schwalbe T., Seifert B., Vogel J., Voigtländer K., Zimdars B. \& ZULKA K.P. 2001: Development of soil fauna at mine sites during 46 years after afforestation. Pedobiologia 45: 243-271.

DunN R.R., Gerahty C.R. \& SANDeRs N.J. 2007: Reproductive phonologies in a diverse temperate ant fauna. Ecol. Entomol. 32: $135-142$.

Gorb S.N. \& Gorb E.V. 1999: Effects of ant species composition on seed removal in deciduous forest in eastern Europe. Oikos 84: 110-118.

Gotelli N.J. \& Ellison A.M. 2002: Assembly rules for New England ant assemblages. Oikos 99: 591-599.

Holec M. \& Frouz J. 2005: Ant (Hymenoptera: Formicidae) communities in reclaimed and unreclaimed brown coal mining spoil dumps in the Czech Republic. Pedobiologia 49: 345-357.

KJELLSSON G. 1985: Seed fate in a population of Carex pilulifera L. Oecologia 67: 416-423.

Kotze D.J. \& Samways M.J. 1999: Support for the multi-taxa approach in biodiversity assessment, as shown by epigaeic invertebrates in an Afromontane forest archipelago. J. Insect Conserv. 3: 125-143.

Laeger T. \& Schultz R. 2005: Ameisen (Hymenoptera: Formicidae) als Beifänge in Bodenfallen - wie genau spiegeln sie reale Abundanzverhältnisse wider? [Ants (Hymenoptera: Formicidae) as supplementary catches in pitfall traps - How exactly do they reflect real abundance?] Myrmecol. Nachr. 7: $17-24$.

Lafleur B., Parsons W.F.J., Bradley R.L. \& Francoeur A. 2006: Ants assemblages and their relationship to habitat factors along a chronosequence of postfire regenerated lichen-spruce woodlands. Environ. Ecol. 35: 1515-1525.

Lock K., Dekoninck W. \& Grootaert P. 2005: Effect of forest developmental stage on centipede communities. Bull. Konin. Belg. Inst. Natuurwet. (Entomol.) 75: 267-270.

MAETO K. \& SATO S. 2004: Impacts of forestry on ant species richness and composition in warm-temperate forests of Japan. Forest Ecol. Manag. 187: 213-223.

Markó B., Kiss K. \& Gallé L. 2004: Mosaic structure of ant communities (Hymenoptera: Formicidae) in Eastern Carpathian marshes: regional versus local scales. Acta Zool. Acad. Sci. Hung. 50(2): 77-95.

McCune B. \& Grace J.B. 2002: Analysis of Ecological Communities. MjM. Software Design, Gleneden Beach, OR, 300 pp.

OINONEN E.A. 1956: On the ants of the rocks and their contribution to the afforestation of rocks in southern Finland. Acta Entomol. Fenn. 12: 1-212.

Ottonetti L., Tucci L. \& Santini G. 2006: Recolonization patterns of ants in a rehabilitated lignite mine in central Italy: Potential for the use of mediterranean ants as indicators of restoration processess. Restor. Ecol. 14: 60-66.

Punttila P. 1996: Succession, forest fragmentation, and the distribution of wood ants. Oikos 75: 291-298.

Punttila P., Haila Y., Pajunen T. \& Tukia H. 1991: Colonisation of clearcut forests by ants in the southern Finnish taiga: a quantitative survey. Oikos 61: 250-262.

Punttila P., Haila Y., Niemelä J. \& Pajunen T. 1994: Ant communities in fragments of old-growth taiga and managed surroundings. Ann. Zool. Fenn. 31: 131-144.

Retana J. \& Cerdrà X. 2000: Patterns of diversity and composition of Mediterranean ground ant communities tracking spatial and temporal variability in the thermal environment. Oecologia 123: 436-444. 
Samways M.J., Caldwell P.M. \& Osborn R. 1996: Groundliving invertebrate assemblages in native, planted and invasive vegetation in South Africa. Agric. Ecosyst. Environ. 59: 19-32.

Schlick-Steiner B.C., Steiner F.M. \& Steiner H. 2005: Effect of extensification of coppice management on central European ant assemblages (Hymenoptera: Formicidae). Entomol. Gener. 28: 23-37.

Schlick-Steiner B.C., Steiner F.M., Moder K., Bruckner A. Fiedler K. \& Christian E. 2006: Assessing ant assemblages: pitfall trapping versus nest counting (Hymenoptera, Formicidae). Insectes Soc. 53: 274-281.

SEIFERT B. 1986: Vergleichende Untersuchungen zur Habitatwahl von Ameisen (Hymenoptera: Formicidae) im mittleren und südlichen Teil der DDR. Abh. Ber. NaturkMus. Görlitz 59(5): 1-124.

SEIFERT B. 1990: Wie wissenschaftlich wertlose Fangzahlen entstehen - Auswirkungen artspezifischen Verhaltens von Ameisen an Barberfallen direkt beobachtet. Entomol. Nachr. Ber. 34: 21-27.

SEIFERT B. 1996: Ameisen, bestimmen, beobachten. Naturbuch Verlag, Berlin, 352 pp.

Siepel H., Meijer J., Mabelis A.A. \& den Boer M.H. 1989: A tool to assess the influence of management practices on grassland surface macrofaunas. J. Appl. Entomol. 108: 271-290.
Steiner F.M. \& Schlick-Steiner B.C. 2004: Edge effects on the diversity of ant assemblages in a xeric alluvial habitat in central Europe (Hymenoptera: Formicidae). Entomol. Gener. 27: $55-62$.

Steiner F.M., Schlick-Steiner B.C., Moder K., Bruckner A. \& Christian E. 2005: Congruence of data from differenent trapping periods of ant pitfall catches (Hymenoptera: Formicidae). Sociobiology 46: 105-116.

Steiner F.M., Schlick-Steiner B.C., Konrad H., Moder K., Christian E., Seifert B., Crozier R.H., Stauffer C. \& BuschINGER A. 2006: No sympatric speciation here: multiple data sources show that the ant Myrmica microrubra is not a separate species but an alternate reproductive morph of Myrmica rubra. J. Evol. Biol. 19: 777-787.

TACK G., VAn den Bremt P. \& Hermy M. 1993: Bossen van Vlaanderen. Een historische ecology. [Forests of Flanders. Historical Ecology.] Uitgeverij Davidsfonds, Leuven, 320 pp.

Vepsäläinen K., Savolainen R., Tiainen J. \& Vilén J. 2000: Successional changes of ant assemblages: from virgin and ditched bogs to forests. Ann. Zool. Fenn. 37: 135-149.

Watt A.D., Stork N.E. \& Bolton B. 2002: The diversity and abundance of ants in relation to forest disturbance and plantation establishment in southern Cameroon. J. App. Ecol. 39: $18-30$.

Received November 29, 2007; revised and accepted February 27, 2008 